\title{
KELEBIHAN PENDUDUK DAN \\ KONSUMSI BERLEBIHAN DALAM KASUS KRISIS \\ AIR DUNIA \\ Oleh: Ainun Jariab*
}

Abstract

Amount of earthling in this time reach 6,6 billion growth level 76 million per year. According to United Nation amount of resident of earth will increase counted 2,6 billion in 2050. Care problem of excess of resident early when natural resources and environment star to destroy. Beside beight growth of resident amount, pattern consume abundant buman being result earth natural resources pressure mount also. This matter because of amount of bigher resident as whole compared to ability of earth fulfill requirement of consumption resident of earth so that growth of high resident and also consumption which is abundant to be considered to be root problems of environment, among others irrigate crisis world. Irrigate crisis happened because of unconscious of human being will total up limited water and also increasing it is amount of buman being owning is same requirement to water. Islam is one of the big religion in the world has important rle in solving environment problem, that is with studying about ethical respon of Islam to clean water and proprietary rights irrigate as natural resource wich provide by nature. Inequal access clean water because of lack of awareness of human being will total up available under the sun water.

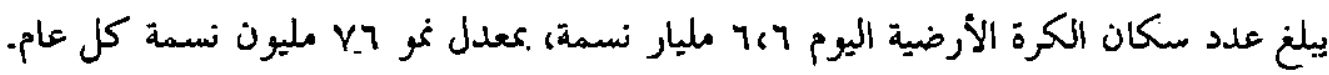

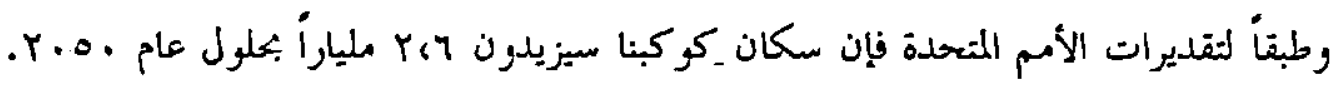
وبالإضافة إلى دعدلات التزايد السكاني العالية، فإن أمناط الاستهالك الحالية تضع أعباء إضافية على الموارد الطبيعية على كوكبنا. ويعد هذان العاماكن (ارتفاع معدلات السكان و أنماط الاستهلاك الحالية) جذر المشكلة البيئية المحالية، ومن بينها أزمة الري العالمية. ترجع أزمة الري الري العالمية إلى عدم وعي الإنسان بارتفاع معدلات الطلب على المياة وفي نفس الوقت بقاء

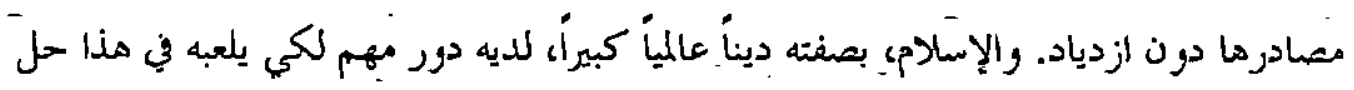
مختلف أوجه هذه الأزمة، وعلى رأسها مشكلة حقوق الري وأورلوياته، المعدلات غيرالعادلة كلحعمول على المياه النظيفة، إضافة إلى قلة الوعي البشبري يمحدودية المصادر الكلية للمياة. Keywords: Krisis lingkungan, kelebiban penduduk, konsumsi berlebihan, krisis air dunia

* Alumni Universitas Gajah Mada E-mai:ainun.jariah.@gmail.com 


\section{A. Pendabuluan}

Krisis lingkungan hidup merupakan salah satu hal yang semakin disadari sebagai masalah yang kompleks dan sedang yang dihadapi umat manusia. Saat ini, bumi mengalami kerusakan yang cukup serius dengan seringnya terjadi bencana alam di berbagai wilayah. Bencana alam seperti tanah longsor di Solok, banjir bandang di Aceh, banjit bandang di Sinjai Sul-Sel, dan lain-lainnya, telah merusak alam dan tempat tinggal manusia. Bencana alam yang telah merenggut ribuan nyawa manusia, menyisakan rentetan masalah sosial berkaitan dengan pendistribusian bantuan bencana alam yang tidak merata sehingga menimbulkan konflik dan sebagainya.

Menghadapi masalah lingkungan, yaitu kekeringan dan kebakaran hutan di musim kemarau dan sebaliknya, pada musim hujan terjadi banjir dan tanah longsor, bukan hanya dengan menggerakkan kegiatan reboisasi dan rehabilitasi lahan secara serius, sebagaimana yang mulai dicanangkan pemerintah. ${ }^{1}$ Ada hal lain yang juga sangat penting untuk diperhatikan dalam bencana ini, ataupun berbagai masalah lingkungan lainnya yang terjadi di Indonesia, yaitu dengan memperhatikan keterkaitan antara krisis lingkungan dengan pertambahan jumlah penduduk yang terus meningkat dan pola konsumsi manusia yang berlebihan.

Pesatnya pertambahan penduduk dunia dan terbatasnya sumber daya alam, bertambahnya penggunaan teknologi modern yang mengakibatkan polusi dan juga pemanfaatan sumber daya alam yang berlebihan mengakibatkan semakin merosotnya kualitas lingkungan hidup. Bumi semakin panas (global warming), udata, sungai dan laut makin kotor serta teracuni, dan lapisan ozon rusak sebagai efek dari rumah kaca. Pengurasan sumber-sumber daya alam dan mineral, perusakan dan pengotoran lingkungan mengakibatkan ketidakseimbangan ekologis. Kurangnya ketersediaan air bersih dan ketidakseimbangan akses terhadap air merupakan persoalan serius yang sedang dan akan menyibukkan umat manusia.

Krisis ait adalah salah satu problem lingkungan yang disebabkan oleh adanya kelebihan penduduk dan pola konsumsi betlebihan. Sehingga dapat dikatakan bahwa antara krisis ait, kelebihan penduduk dan konsumsi berlebihan, ketiganya saling berpengaruh satu sama lain. Semakin banyak orang, berarti semakin banyak jumlah air yang dibutuhkan untuk konsumsi sehari-hari. Semakin banyak orang yang membutuhkan air bersih, juga berarti akan semakin banyak sumber daya-air yang akan diambil di mana jumlah air dunia tersebut dalam kondisi yang terbatas. Dalam hal ini, krisis air dunia bukan hanya dalam hal kuantitas air yang berkurang, namun juga dalam hal kualitas air yang menurun. Persoalan yang muncul pada segi kuantitas dan kualitas air bermacam-macam, seperti berkurangnya sumber daya alam air, ketidaksetaraan akses air bersih, polusi air, dan privatisasi ait.

1 Sejak awal tahun 2006, menyediakan anggaran-sebesar 4 triliun untuk menanam pohon. Lihat Salam Tribun, "Menghadapi Bencana Alam", dalam Tribun Timur, Rabu, 27 Desember 2006, p. 16. 
Dari pernyataan-pernyataan tersebut di atas, muncul beberapa pertanyaan: Pertama, secara lebih khusus, bagaimana persoalan air menggambarkan pentingnya pembahasan tentang kelebihan penduduk dan konsumsi berlebihan? Kedua, apa saja persoalan-persoalan etis yang terkait dengan krisis air dunia? Ketiga, bagaimana Islam dapat mengajukan respon etis atas permasalahan krisis air dunia saat ini?

\section{B. Dampak Kelebiban Penduduk dan Konsumsi Berlebihan terbadap Kebidupan Manusia}

Pengertian kelebihan penduduk dalam kamus adalah kepadatan jumlah penduduk di sebuah area yang mencapai titik yang sangat padat sehingga mengakibatkan habisnya sumber daya alam, atau merosotnya kondisi lingkungan. ${ }^{2}$ Paul Ehrlich mengilustrasikan tentang ledakan penduduk dengan kalimat berikut:

'Psychologically, the population explosion first sunk in on a stinking bot night in Delbi. The streets were alive with people. People eating, people washing themselves, people sleeping, people working, arguing and screaming. People reaching their bands in trough taxi windows to beg. People shitting, people pissing. People banging off buses. People driving animals through the streets. People, people, people."

Menurut Lindsay, tidak ada indikasi yang jelas terhadap persoalan kelebihan penduduk. Jika padatnya penduduk yang menjadi indikatornya, maka Bermuda dan Monako akan menjadi area krisis, sedangkan Nigeria dan Ethiopia mestinya menjadi negara yang makmur. Faktor-faktor lainnya, seperti tingkat pertumbuhan tata-rata penduduk, juga merupakan teka-teki yang tidak tentu ukurannya. Lindsay juga menyetujui bahwa memang ada wilayah-wilayah yang mengalami kekurangan sumber daya alam dan akan mengalami kelaparan, tetapi mengurangi jumlah penduduk bukanlah solusi yang tepat untuk mengatasi kemiskinan. Karena menurutnya, penyebab kelaparan mereka adalah kemiskinan, bukan karena adanya kelebihan penduduk. Hal tersebut merupakan tanggung jawab pemerintah dalam penanganan sumber daya alam. ${ }^{4}$

Secara jelas, istilah kelebihan penduduk bukan hal yang sederhana untuk digambarkan secara sekilas. Setiap masyarakat berbeda keadaannya dan tidak dapat disamaratakan. Ketika berbicara mengenai keadaan suatu masyarakat, acuannya mesti pada tingkat pertumbuhan penduduk rata-rata, standar kehidupan, gaya hidup, budaya, teknologi yang tersedia, sumber daya alam, dan pertumbuhan ekonomi.

2 American Heritage (1992), The American Heritage Dictionary of the English Language, $3^{\text {rd }}$ edition, United States of America: Houghton Mifflin Company, p. 1291.

${ }^{3}$ Bjorn Lomborg (2001), The Skeptical Environmentalis, United Kingdom: Cambridge University Press, p. 48.

+ Ibid. 
Hingga saat ini, penulis belum menemukan data-data penelitian ataupun analisa dari para ahli demografi maupun lingkungan yang mendaftar wilayah-wilayah yang dapat dikategorikan mengalami kelebihan penduduk. Data-data yang ada adalah data jumlah penduduk, tingkat kepadatan penduduk pada suatu negara, pendapatan perkapita, harapan umur, tingkat kelahiran, tingkat kematian, jumlah penduduk berdasarkan umur, daya dukung bumi, ekologi foot-print, dan data-data lainnya.

Jumlah penduduk dunia saat ini kira-kira 6 milyar dengan tingkat pertumbuhan penduduk antara tahun 1980 sampai tahun 2000 berkembang dari 4,4 milyar menjadi 6 milyar. Berdasarkan proyeksi kependudukan, pada tahun 2015 kurang lebih penduduk akan bertambah secara keseluruhan lebih dari 7 milyat. Sebagian besar dari pertumbuhan ini akan menempati di negara-negara yang berpendapatan rendah dan menengah. ${ }^{5}$

Menurut data Bank Dunia, kelebihan penduduk terjadi di negara-negara yang berpendapatan rendah dan menengah. Hal tersebut disebabkan oleh jumlah penduduk yang lebih tinggi di negara-negara tersebut dibandingkan dengan negara-negara yang berpendapatan tinggi. Selain itu juga karena standar kebutuhan dasar penduduk di negara-negara berpendapatan rendah dan menengah tidak dapat terpenuhi dengan baik. $^{6}$ Sementara, penelitian lain menyebutkan bahwa kelebihan penduduk akan berpengaruh pada kualitas kehidupan setiap penduduk di wilayah tersebut. ${ }^{7}$

Kemudian, jumlah penduduk dunia tidak akan menjadi masalah jika tidak ada keterbatasan tanah (daratan), keterbatasan air, dan keterbatasan sumber daya alam. Sayang sekali, dengan adanya kelebihan penduduk, kemudian muncul tantangan dalam pembagian yang sama besar dengan jumlah yang lebih kecil serta porsi yang lebih kecil pula.

Berdasarkan pemaparan tabel di akhir tulisan ini, penulis merumuskan kajian dan peran apa saja yang bisa dimasuki agama. Agama akan banyak berperan dalam pembentukan sikap dan pola hidup manusia baik secara individu maupun sosial dan hal-hal yang berkaitan dengan moralitas. Oleh karena itu, perilaku seluruhnya merupakan masalah yang harus dan bisa dikaji oleh agama. Agama telah banyak memperingatkan akan terjadinya kerusakan yang disebabkan oleh manusia, yaitu dari segi jumlah maupun perilaku hidupnya. Misalnya, kepunahan makhluk-makhluk

. 5 The World Bank, "Population Growth Rate," dalam www.worldbank.org/depweb/english/ modules/social/pgt/chart1, dikutip tgl. 10 Agustus 2006. Situs ini menyediakan tentang latar belakang umum dari faktor-faktor yang mempengaruhi angka pertumbuhan penduduk dan beberapa masalah' yang mungkin betkembang jika penduduk bertumbuhkembang dengan begitu cepat.

6 The World Bank, "Population Growth Rate," dalam wwwworldbank/org/depweb/english/ modules/social/pgr/chart2, dikutip tgl. 10 Agustus 2006.

7 -Sutikno dan Maryunani (2006), Ekonomi Sumber Daya Alam, Malang: Badan Penerbit Fakultas Ekonomi UNIBRAW, p. 62. 
lain, seperti tanaman dan hewan tentunya bukan hal yang dibenarkan agama.

Sumber daya alam air yang menjadi bagian dari ritual keagamaan merupakan unsur yang sangat penting dalam kehidupan keagamaan. Kurangnya air atau tercemarnya air tentu menjadi persoalan yang cukup besar bagi umat beragama. Kesucian air merupakan syarat dalam pelaksanaan ritual-ritual. Begitu pula sampah atau limbah industri dan rumah tangga yang jumlahnya meningkat, merupakan bagian dari masalah agama yang identik dengan kesucian dan kebersihan. Ajaran agama selalu menganjurkan hidup bersih dan sehat agar manusia hidup lebih mampu menjalankan tugas-tugasnya di muka bumi.

Dalam struktur mikro, kemiskinan dapat menjadi bagian dari persoalan agama. Agama memiliki kemampuan untuk mendistribusikan kekayaan seseorang atau perusahaan dalam ajarannya mengenai zakat, infak atau pun shadaqah. Dalam struktur makro, terdapat struktur sosial-ekonomi global yang telah menyebabkan kerusakan lingkungan yang memerlukan respon dari agamawan untuk dapat menjawab persoalan-persoalan yang muncul di balik struktur sosial ekonomi global tersebut dengan memperkuat fungsi kontrol terhadap berbagai kebijakan pemerintah.

Perlu diperhatikan bahwa masalah lingkungan yang dihadapi oleh negara-negara maju dan negara-negara berkembang memiliki perbedaan penyebab. Penyebab utama di negara maju adalah industrialisasi yang banyak menimbulkan pencemaran (tanah, air, dan udara), baik melalui proses produksi maupun konsumsi. Sedangkan di negara berkembang, permasalahan lingkungan disebabkan oleh kemiskinan yang memaksa masyarakat untuk merusak lingkungan. Misalnya penebangan hutan untuk keperluan lahan pertanian atau pemukiman.

Dalam pemetaan kelebihan penduduk dan konsumsi berlebihan, diantaranya terdapat aspek berkurangnya sumber daya air. Jumlah penduduk yang semakin meningkat telah menyebabkan kekurangan air, penurunan kualitas air, beserta pendistribusiannya. Sutikno menyatakan bahwa permasalahan manusia yang berkaitan dengan sumber daya alam air dapat dikaitkan dengan empat hal, yaitu pertambahan penduduk, kebutuhan pangan (konsumsi), peningkatan industrialisasi, dan perlindungan ekosistem terhadap teknologi. ${ }^{8}$

\section{Fungsi dan Keterlibatan Agama dalam Persoalan Air}

Untuk mengkaji fungsi dan keterlibatan agama dalam persoalan air, perlu kiranya secara lebih terinci penulis membahasnya dalam bagian-bagian berikut ini: 1. Relevansi agama

Air menjadi bagian dari kehidupan manusia sehari-hari. Dari air manusia dapat belajar tentang jalan menuju kedamaian dan kebebasan. Manusia dapat belajar

\footnotetext{
8 Sutikno dan Maryunani, Ibid., p.165.
} 
kepentingan pihak-pihak tertentu terhadap air disebabkan-oleh kerakusan, pemborosan, dan ketidakadilan.

Gary Gardner dalam bukunya secara umum telah mengkaji kesinambungan antara agama dan persoalan-persoalan lingkungan global.' Dalam tulisannya, Gardner menjelaskan bahwa semestinyalah para agamawan dan institusinya bekerjasama dengan para ahli lingkungan dan para pemerhati lingkungan dalam satu hal, yaitu usaha untuk kebetlanjutan kehidupan dunia. ${ }^{10} \mathrm{Hal}$ ini disebabkan karena kehidupan yang dijalani saat ini masih akan terus betlanjut pada generasi berikutnya sehingga perlu dipikirkan bagaimana agar kehidupan ini akan terus menjadi milik generasi berikutnya secara lebih baik lagi, sedangkan apa yang terjadi saat ini adalah krisis lingkungan yang berpengaruh pada berbagai aspek kehidupan manusia. Tidak mungkin keberlanjutan hidup berjalan lebih baik jika kehidupan saat ini telah rusak.

Namun Gardner juga melihat bahwa masih ada konflik-konflik antara agama dan sains yang periu diselesaikan terlebih dahulu. Meski sebenamya kelompok agama dan ahli lingkungan masing-masing memiliki urusan yang betbeda dalam perbincangan tentang keberlanjutan hidup manusia di masa depan.

Menurut Gardner, agama memiliki sumber-sumber kekuatan, yaitu dalam hal membentuk pandangan hidup masyarakat, memiliki pengaruh terhadap otoritas moral, agama pun memiliki banyak pengikut yang taat, sering mempunyai kekuatan finansial dan aset institusi, dan juga kekuatan penggerak ekonomi masyarakat, serta sebagai aset pembangunan masyarakat. Seluruh aset tersebut dapat digunakan untuk membantu pembangunan sebuah masyarakat yang adil dan kebetlanjutan hidup yang berwawasan lingkungan." Di sini, ahli lingkungan memiliki kekuatan peran dalam hal penjelasan secara obyektif akan kondisi alam dan data-data lingkungan yang dapat membantu agama untuk memberikan respon terhadap prediksi-prediksi yang dapat diuji tersebut untuk memberikan pandangan-pandangannya terhadap pertanyaan mengenai maksud diciptakannya manusia dan alam semesta. ${ }^{12}$.

Karakteristik agama yang dikaji oleh Gardner memberi gambaran lebih jelas tentang substansi pengaruh agama terhadap lingkungan, yaitu pandangan hidup akan membentuk sikap terhadap alam semesta; ritual digunakan untuk menguasai sumber daya alam, etika yang berpengaruh terhadap penggunaan sumber daya alam dan distribusinya, serta kekuatan institusi agama dapat pula membentuk perilaku dan kébijakan dalam banyak hal yang berpengaruh pada lingkungan, baik itu hal yang lebih baik ataupun hal yang lebih buruk. ${ }^{13}$

${ }^{9}$ Gary Gardner (2002), Invoking the Spirit: Religion and Spirituality in the Quest for a Sustainable IVorld, USA: Worldwatch Institute, p. 3.

${ }^{10} \mathrm{Ibid}, \mathrm{p} .5$.

"Ibid. 
Untuk hidup berkelanjutan, institusi agama dan para pemimpin agama memiliki kekuatan untuk mengusahakan keberlanjutan dalam lima hal, yaitu: kapasitasnya untuk membentuk sebuah pandangan hidup, memiliki otoritas moral, pengikut yang banyak, sumber daya alam yang bernilai, dan kapasitas membangun sebuah komunitas. Agama juga berpengalaman dalam menginformasikan perspektif kita atas isu-isu penting akhir-akhir ini. ${ }^{14}$

Meskipun agama bisa menjadi sumber pemecahan masalah, dalam hal-hal tertentu agama dapat menjadi sumber masalah itu sendiri. Namun, dalam tulisan ini yang akan dikaji adalah bagaimana agama dapat menjadi sumber pemecahannya. Agama sebagai sumber pemecahan mengandaikan perlunya suatu rumusan etis untuk memperkuat penyelesaian masalah dan mampu mendorong para pemeluknya untuk mengambil pilihan-pilihan etis yang sulit. Pernyataan dari agama itu pun bukan sekedar pernyataan normatif, namun bagaimana etika praktis menggunakan sumbersumber ajaran agama (teks) dalam konteks yang baru.

Ilmuwan lain yang berbicara tentang peranan agama dalam persoalan-persoalan lingkungan adalah Vasudha Narayanan yang menyebutkan bahwa ada tiga hal dalam agama yang dapat menjadi sumber solusi, yaitu teks (sumber pemahaman/ ajaran), candi (tempat ibadah, lembaga keagamaan), dan gutu (pemimpin agama). ${ }^{15}$

2. Keterlibatan agama

Kuntowijoyo dalam tulisannya "Dari Rasionalitas Menuju Transendensi," mengajukan tesis bahwa krisis lingkungan yang terjadi saat ini ada kaitannya dengan peranan agama, yaitu perubahan konsep-konsep teologi. Misalnya, konsep "khalifah" dalam Islam; bahwa manusia dijadikan sebagai khalifah di muka bumi, bahwa bumi dan langit disuruh tunduk kepada manusia atau diperuntukkan bagi manusia. Konsep khalifah seharusnya diubah dari konsep "menguasai" menjadi "bersahabat" dengan alam, sehingga jika konsep bersahabat dengan alam diterapkan, manusia akan lebih mempunyai perhatian kepada lingkungan, kita tidak akan merampok alam kita, tapi kita berbuat baik kepada alam. ${ }^{16}$

Selain itu Kuntowijoyo juga berpendapat bahwa krisis lingkungan dapat diatasi jika agama berperan dalam memberi pengaruh terhadap redefinisi kemanusiaan kita. Menurutnya, selama ini kemanusiaan kita ditentukan oleh nilai-nilai yang diletakkan oleh renaisans, pada waktu manusia menemukan bahwa ukuran yang tertinggi adalah

${ }^{12}$ Audrey R. Chapman (2000), "Introduction", dalam Consumption, Population, and Sustainability: Perspectives from Science and Religion, California: Island Press, p. 6.

${ }^{13}$ Gary Gardner, op.cit., p. 10.

${ }^{1+}$ Ibid, p. 11.

${ }^{15}$ Vasudha Narayanan (2001), "Water, Wood, and Wisdom: Ecological Perspectives from the Hindu Traditions," dalam Daedalus, Journal of the American Academy of Arts and Sciences, Vol. 130, No. 4, pp. 183-203. 
manusia, maka manusia hanya diukur dari rasionalitasnya. Jika kita mampu mengubah . pandangan tersebut dengan memasukkan nilai-nilai agama, maka humanisme kita tidak lagi diukur dengan rasionalitas tapi diukur dengan transendensi. Kita mencoba meletakkan nilai-nilai normatif yang ada dari wahyu, dan di situlah kemajuan manusia dan kemanusiaan itu sendiri diukur. Maka diharapkan bahwa peranan agama memberikan solusi atas krisis lingkungan akan lebih besar lagi. ${ }^{17}$

Ilmuwan di bidang Etika, Roger Shinn menegaskan tentang perlunya menggabungkan antara etika dan pendapat-pendapat teknis dan untuk tanggung jawab moral dan ilmu pengetahuan. Dia menekankan bahwa keberlanjutan lingkungan, keadilan global, dan masa depan manusia merupakan isu-isu agama yang paling besar. Agama menyentuh beberapa persoalan yang terdalam dari manusia hubungannya dengan makhluk lain dan alam semesta. ${ }^{18}$

Dalam bahasan berikutnya akan dibahas mengenai respon etis Islam terhadap persoalan-persoalan etis dalam kasus krisis air dunia sebagai bentuk dari peranan agama dalam problem lingkungan yang terjadi. Di sini penulis melihat dua persoalan etis utama dalam kasus krisis air dunia, yaitu ketidaksetaraan akses air bersih dan hak kepemilikan air. Ketidaksetaraan akses air bersih telah menimbulkan konflik antata manusia sedangkan persoalan mengenai hak kepemilikan air berkaitan dengan sistem ekonomi global yang telah melahirkan privatisasi sumber-sumber mata air yang kemudian diperdagangkan, sehingga muncul pertanyaan-pertanyaan mengenai hak azasi manusia terhadap sumber daya alam, termasuk air yang disebutkan PBB sebagai hak asasi manusia. Apakah layak sebuah hak kemudian diperdagangkan?

\section{Respon-Respon Muslim atas Persoalan Etis dalam Air}

1. Ketidaksetaraan Akses Air Bersih

Nawal H. Ammar, seotang professor Muslim yang konsentrasi dalam isu-isu keadilan dan kebijakan publik, mengusulkan konsep kerangka berfikir bay'a sebagai pedoman prinsip teologi dalam menghadapi permasalahan krisis lingkungan yang dihadapi saat ini. Dia mengajukan pemikiran bahwa ketidakhadiran konsep bay'a dalam prinsip teologi telah memberi andil terhadap krisis lingkungan yang terjadi. ${ }^{19}$

Menurut Ammar, bay'a yang berasal dari bahasa Arab berarti perilaku yang mencerminkan rasa malu atas kehormatan dan harga diri bukan merupakan ekspresi ketakutan. Namun ini adalah perilaku yang menggambarkan keseimbangan, cara penghargaan, dan perlindungan terhadap semua ciptaan Allah. ${ }^{20}$

- Menurut Ammar, dalam menghadapi ketidakadilan distribusi sumber daya

38.

${ }^{16}$ Kuntowijoyo (1990), “Dari Rasionalitās Menuju Transendensi,” dalam Inovasi No No. 7 Th. IV, p.

${ }^{17}$ Ibid, p. 39.

${ }^{18}$ Audrey, "Introduction," dalam Consumption, Population, and Sustainability, Op.Cit., p. 17-18. 
alam, umat Islam sebaiknya mengacu kepada sistem perekonomian Islam. Terdapat dua prinsip yang digunakan dalam sistem ekonomi Islam, yaitu keadilan dalam bertransaksi dan mengutamakan kepentingan orang banyak daripada individu.

Ptinsip pertama adalah segala bentuk bubungan antar manusia barus berdasarkan keadilan dalam bertransaksi dan tidak ada klaim atas sumber daya alam. Jika dibandingkan dengan pandangan agama lain mengenai keinginan manusia, keadilan dalam berinteraksi (just interaction) dalam perspektif Islam tidak sama dengan konsep pemadaman keinginan dalam ajaran Buddha. Karena Islam memandang keinginan/ hasrat sebagai sumber kebahagiaan sedangkan ajaran Buddha melihatnya sebagai sebuah penderitaan. Permasalahannya lebih terletak pada proses pencapaian terhadap keinginan tersebut, sehingga dalam ajaran Islam, keinginan orang banyak lebih diutamakan daripada keinginan pribadi. ${ }^{21}$

Hasrat atau nafsu manusia memang dapat mempengaruhi sikap adil, karena keadilan dapat pula berarti pencapaian keseimbangan yang sulit dicapai karena hasrat manusia menginginkan banyak hal yang kadang tidak terkendali. Ammar memberi penjelasan bahwa bersungguh-sungguh dalam bekerja, sikap adil, teliti, serta jujur dalam bettransaksi, merupakan bagian dari sebuah keadilan dalam interaksi antar manusia.

Prinsip kedua yang petlu diperhatikan adalah masyarakat banyak memiliki prioritas utama dibandingkan individu. Islam menekankan konsep mengutamakan kepentingan umum daripada kepentingan pribadi. Penekanan Islam terhadap hak umum daripada hak individu diwujudkan melalui isu-isu mengenai keadilan distribusi. Hal tersebut diilustrasikan dalam tiga hal berikut, yaitu:

a) Kewajiban setiap umat Islam untuk mengeluarkan zakat. Bahwa perlu ada kepedulian dari orang yang memiliki harta kepada orang-orang yang tidak mampu. Penanaman sikap dan pandangan hidup untuk selalu berbagi ini merupakan hal yang terpenting dalam penggunaan sumber daya alam. Ketika kita menggunakan sumber daya alam, maka perlu dipikirkan untuk saling berbagi kepada orang lain. Tidak hanya menikmati kekayaan secara sendirian tetapi prinsip utilitarianisme perlu diterapkan dengan mengutamakan kebersamaan daripada kebutuhan

\footnotetext{
${ }^{19}$ Nawal H. Ammat, op.cit., p. 134.
}

${ }^{20} \mathrm{Ibid}$. Adapun mengenai arti hay'a yang sebenamya belum dapat ditemukan oleh penulis sejauh studi yang telah dilakukan, karena tidak ada teks Arab dalam kamus yang menjelaskan arti dari kata bay'a tersebut. Adapun kata yang berdekatan artinya dengan bay'a adalah baga'yang berarti rasa malu, sedangkan dalam bentuk kata lain, yaitu bay'ab adalah badan, lembaga, bentuk, atau rupa, namun artian tersebut tidak mendekati pemahaman terhadap konsep hay'a yang diajukan oleh Nawal H. Ammar. Pemahaman lain terhadap bay'a adalah kesederhanaan (modesty), maksudnya adalah sikap hidup sederhana akan berpengaruh pada menurunnya tingkat konsumsi manusia terhadap kebutuhan ptimer, sekunder, dan tersier.

${ }^{21}$ Ibid., pp. 135-136. 


\section{pribadi. ${ }^{22}$}

b) Pentingnya seorang pemimpin betkualitas yang akan berperan dalam membangun sebuah keadilan dalam masyarakat. Pemimpin yang adil akan memperhatikan hal keseimbangan dalam penggunaan. sumber daya alam untuk kepentingan - masyarakatnya. ${ }^{23}$

c) Cara pandang manusia terhadap "yang lain" (the other) atau perbedaan dalam masyarakat, bahwa Islam menghargai umat selain beragama Islam, menghargai perbedaan yang ada dalam masyarakat sebagaimana termaktub dalam al-Qur`an surat Yunus: 99 dan surat Hujurat: $13 .^{24}$

Ammar merumuskan lima aturan yang dinasihatkan Islam dalam penggunaan sumber daya alam, yaitu: ${ }^{25}$

a: Menggunakan sumber daya alam secara seimbang, tidak dengan cara berlebihlebihan;

b. Memperlakukan alam dan sumber dayanya secara baik;

c. Tidak metusak, menyalahgunakan atau mengubah alam dalam betbagai cara;

d. Saling berbagi sumber daya alam dengan manusia dan habitat lainnya; dan

e. Melakukan konservasi (perlindungan dan penghematan).

Pendapat lain dalam konsumsi berlebihan, yaitu Abdul Cader Asmal dan Mohammed Asmal dalam buku berjudul Consumption, Population, and Sustainability: Perspectives from Science and Religion mengutip beberapa ayat al-Qur'an yang menjelaskan tentang etika konsumsi bahwa “jagalah keseimbangan dengan persamaan.” (Q.S. 55: 3-9): "Dia menciptakan manusia. Mengajarnya pandai berbicara. Matabari dan bulan (beredar) menurut perbitungan. Dan tumbub-tumbuban dan pobon-pobonan kedua-duanya tunduk kepada-Nya. Dan Allab telab meninggikan langit dan Dia meletakkan neraca (keadilan). Supaya kamu jangan melampaui batas tentang neraca itu. Dan tegakkanlah timbangan itu dengan adil dan janganlah kamu mengurangi neraca itu." Yang dimaksud dengan menjaga keseimbangan secara adil adalah memperhatikan kewajibankewajiban manusia dalam hal makan dan minum, agar tidak berlebih-lebihan sebagaimana yang termaktub dalam Q.S. Al-A'raf (7): 31, kemudian meyakini rezki Tuhan yang diberikan kepada setiap hamba-hambaNya sebagaimana dalam Q.S. AlIsra' (17): 30, serta adanya ketentuan rezki yang kita dapatkan dari Tuhan sebagaimana dalam Q.S. Fushshilat (41): $10^{26}$

Selanjutnya Asmal mengutip pernyataan Naseef tentang perlunya menjaga keseimbangan antara hal-hal yang menjadi kebutuhan manusia dan memikirkan keberlanjutan alam semesta. Selain itu, kita juga perlu menjaga keseimbangan antara pemanfaatan kekayaan alam semesta untuk kebutuhan manusia saat ini dan

\footnotetext{
${ }^{22}$ Ibid., pp. 137-138.

${ }^{23}$ Ibid., pp. 138-139.

${ }^{24}$ Ibid. pp. 139-140.
} 
kebutuhan generasi yang akan datang. ${ }^{27}$

Ibrahim Ozdemir dalam tulisannya "Environmental Ethics from a Qur'anic Perspective” menjelaskan konsep keadilan dan keseimbangan dalam kehidupan manusia. Manusia harus memperhatikan keseimbangan alam dalam penggunaannya serta dalam berinteraksi di dalam masyarakat. Dalam kaitannya dengan masalah air, Ibrahim Ozdemir mengutip Sunnah Nabi mengenai penggunaan air secara seimbang atau tidak betlebih-lebihan. Nabi Muhammad telah melarang umatnya menggunakan air secara berlebih-lebihan bahkan dalam melaksanakan suatu kewajiban bersuci, seperti berwudhu. Perbuatan berlebih-lebihan dalam menggunakan air dihukumkan makruh (dibenci). Kutipan kisah dari Hadis tersebut adalah.:28

"Pada suatu waktu Rasulullah saw. melihat Sa'id melaksanakan wudhu. Lalu Beliau melihat Sa'id menggunakan air yang sangat banyak, Nabi lalu menegurnya dengan berkata: "Apa yang sedang engkau lakukan wahai Sa'id? Engkau telah berlebihan menggunakan air." Sa'id langsung menjawab: "Dapatkah dikatakan berlebihan menggunakan ait meski ketika kita berwudhu?" Rasulullah menjawab: "Ya, bahkan ketika engkau berwudhu di tepian sungai."

Kisah dalam hadis tersebut bukan hanya merujuk pada penggunaan air yang berlebihan namun juga menjadi dasar dalam perilaku konsumtif manusia. Kisah tersebut juga merupakan peringatan, ketika jumlah penduduk semakin meningkat maka memerlukan sumber daya air yang juga banyak. Hadis tersebut juga mengingatkan agar selalu bersikap hati-hati dalam menggunakan air, meskipun dalam kondisi berlimpah air dan untuk memenuhi kewajiban agama. Jika sikap kehatihatian tidak dijaga, maka akan begitu banyak orang yang akan membuang air dengan percuma setiap hari.

Berdasarkan uraian mengenai respon Islam terhadap akses air bersih, maka dapat disimpulkan sementata bahwa ada tiga aspek yang perlu diperhatikan dalam menyelesaikan ketidaksetaraan akses terhadap air bersih dalam Islam. Pertama, prinsip keadilan, yang berlaku untuk setiap pengguna air, baik individu maupun air yang dikelola oleh negara atau perusahaan. Keadilan yang tidak hanya mengedepankan nafsu pribadi atau keinginan negara dan perusahaan, namun keadilan yang lebih mengutamakan kebutuhan masyarakat. Keadilan dalam hal perolehan air bersih masih sulit untuk diterapkan, karena kondisi air setiap wilayah tidak sama. Jika di suatu

\footnotetext{
${ }^{25}$ Nawal H. Ammar, op.cit., p. 144.
}

- ${ }^{26}$ Abdul Cader Asmal dan Mohammed Asmal (2000), "An Islamic Perspective," dalam Consumption, Population, and Sustainability: Perspectives from Science and Religion, USA: Island Press, p. 159.

${ }^{27}$ Ibid.

${ }^{28}$ Ibrahim Ozdemir (2003), "Environmental Ethics from a Qur'anic Perspective," dalam Islam and Ecology: A Bestowed Trust, R. Foltz, F. Denny, dan A. Baharuddin ed., Cambridge: Harvard University Press, p. 14. 
wilayah kualitas air buruk, apakah menjadi tanggung jawab wilayah yang memiliki air bersih untuk bersikap adil dengan membagikan air bersih yang diperolehnya kepada penduduk di wilayah yang buruk kualitas airnya? Siapa yang bertanggung jawab atas ketidakadilan dalam hal akses air bersih? Dalam kondisi bagaimana individu atau negara dan perusahaan dikatakan adil atau tidak adil dalam akses air bersih masyarakat?

Kedua, prinsip tidak berlebih-lebihan dalam setiap perbuatan. Hal ini berkaitan pula dengan sikap hemat dan tidak boros dalam menggunakan air. Meski pada teks ayat Q.S. Al-A'raf (7): 31, menyebutkan larangan tentang betlebih-lebihan dalam hal makan dan minum, namun ayat tersebut dapat dikiaskan pada hal-hal lain, misalnya konsumsi secara umum.

Ketiga, prinsip kehati-hatian dalam penggunaan sumber daya alam. Sikap bethatihati ini maksudnya adalah kehati-hatian dalam menggunakan ait meski dalam kondisi berkecukupan.

Ketiga respon etis tersebut merupakan tanggung jawab individu dalam pembentukan sikap pribadi. Sikap individu bukan berarti tidak memiliki dampak nyata dalam perubahan keadaan mengenai ketidakadilan distribusi air. Perubahan tidak akan terjadi secara langsung namun keadaan akan berubah jika segera dimulai dari pembentukan sikap pribadi masing-masing individu sebagai bentuk tanggung jawab moral terhadap keadaan orang lain dan sekitarnya. Inilah anjuran Islam untuk memulai dari dirimu sendiri (ibda'bi nafsik).

2. Hak Kepemilikan Air

Dalam tulisannya "The Basis for a Discipline of Islamic Environmental Law," Othman Abd-At-Rahman Llewellyn dalam penjelasannya mengenai Hukum Lingkungan dalam Islam, memasukkan hukum air dalam bagian hak-hak penggunaan sumber daya alam. ${ }^{29}$ Menurutnya, air tidak dapat dimiliki secara pribadi dalam kondisi alamiah, air sebagai sumbernya dimiliki oleh umum sebagai kekayaan umum. Setiap orang mesti menggunakannya secara tidak betlebih-lebihan meski dalam kondisi yang berlimpah-limpah, karena hal itu termasuk sikap-konsumsi yang berlebihan, atau pun tidak mengurangi kualitas air dengan pencemaran. Pembatasan penggunaan air meningkat bersamaan dengan bertambah langkanya sumber air. Menggunakan air sebaiknya sesuai dengan kebutuhan dan dikonsumsi secukupnya. Mengutamakan hak terhadap mereka yang kehausan daripada hak-hak penggunaan air lainnya ${ }^{30}$

Al-Qur'an dalam Q.S. Al-Qamar: 28: 'Dan beritakanlah kepada mereka babwa sesunggubnya air itu terbagi antara mereka; tiap-tiap giliran minum dihadiri (oleb mereka yang

29 Othman Abd-Ar-Rahman Llewvellyn (2003), "The Basis for a Discipline of Islamic Environmental Law," dalam Islam and Ecology: A Bestowed Trust, R. Foltz, F. Denny, dan A. Baharuddin ed., Cambridge: Harvard University Press, pp. 203-205. 
punya giliran)," menunjukkan bahwa air merupakan hak milik umum. Sebagaimana hadis Nabi bahwa "Setiap orang berbagi dalam tiga hal, yaitu air, padang rumput, dan api." Dalam hadis lain juga disebutkan larangan menahan dan menyimpan air terhadap mereka yang membutuhkan serta larangan menggunakan air secara berlebihlebihan: 'Berlebib-lebiban dalam menggunakan air dilarang, babkan jika engkau mempunyai sumber air sebanyak air di sungai. ${ }^{\text {\$1 }}$

Dalam sistem hukum Islam klasik, ${ }^{32}$ hak air ditetapkan sebagai yang utama dan terpenting katena ait dibutuhkan untuk menghilangkan dahaga setiap orang. Hak utama ini bukan hanya untuk manusia namun juga untuk hewan. Demikian pula dengan sistem irigasi harus tersedia untuk semua makhluk yang membutuhkannya, dan harus dihindarkan dari polusi karena hal tersebut juga berarti menjaga hak-hak pengguna air di bagian hilit. ${ }^{33}$

Berkaitan dengan hal tersebut, mengenai air minum dalam kemasan (AMDK) yang telah banyak diproduksi perusahaan-perusahaan asing maupun lokal, sering dikritisi sebagai privatisasi sumber mata air, maka hal tersebut mungkin saja merupakan usaha berupa jasa mereka untuk memindahkan sumber mata air ke dalam kemasan sehingga memudahkan setiap orang untuk mengonsumsinya. Maka apakah menjual air minum dalam kemasan dapat dikatakan sebagai pelanggaran hak asasi manusia terhadap pengambilan sumber mata air yang nota bene adalah hak milik umum ataukah sebagai suatu perdagangan jasa sebagaimana usaha-usaha jasa lainnya?

Undang-Undang Sumber Daya Air No. 7 tahun 2004 yang sudah diterbitkan mendukung komersialisasi dan privatisasi air. Dengan terbitnya Undang-Undang tersebut berarti akan ada orang atau badan yang bisa memiliki sumber-sumber air untuk dijadikan barang dagangan (privatisasi). Masyarakat yang paling dirugikan adalah para petani serta peternak ikan karena mereka harus membeli air untuk sawah dan ternak mereka. Betapa mahalnya biaya yang harus mereka tanggung serta harga beras dan ikan yang menjadi kebutuhan pokok manusia!

Oleh karena itu pula, sudah menjadi kewajiban dari segenap umat beragama untuk merespon keadaan tersebut. Umat beragama selayaknya tidak hanya mengejar kesucian diri sendiri namun mulai untuk lebih memikirkan nasib orang lain.

Selanjutnya, hak dan kepemilikan air dapat dikategorikan dalam dua hal, yaitu: 1) air sebagai milik pribadi dapat diberikan untuk diperdagangkan; atau 2) air sebagai hak milik umum yang tidak dapat diperdagangkan. Sehingga kemungkinan untuk

\section{${ }^{30}$ Ibid.}

${ }^{31}$ Richard C. Foltz (2005), "Water in Islam," dalam Encyclopedia of Religion and Nature Volume II, Bron R. Taylor ed., London \& New York: Thoemmes Continuum, pp. 1715.

${ }^{32}$ Hukum Islam klasik tètbentuk pada abad ke-8-dan ke-9 yang dikenal dengan empat mazhab Sunni: Syafi'i, Maliki, Hanafi, dan Hanbali, ditambah mazhab kelima yaitu Ja'fari sebagai Syi'ah.

${ }^{33}$ Richard C. Foltz, op.cit. 
hak untuk menjualbelikan air dapat diberikan. Hanya saja selama ini air yang dijual tersebut adalah sumber mata air alami yang harus dikelola oleh negara namun telah dikelola dalam bentuk lain yang merugikan masyarakat sekitarnya. Masalahnya adalah, kebutuhan masyarakat saat ini terhadap air dalam bentuk kemasan sudah tidak dapat dihindarkan lagi, namun konsumsi yang betlebihan terhadap air kemasan dan ketidakhati-hatian dalam konsumsi air menjadikan produsen air terus memproduksi air kemasan yang berarti menguras sumber daya air lebih banyak.

Memperhatikan hal tersebut, maka perlu diperhatikan bahwa semestinyalah konsumsi terhadap air minum dalam kemasan memperhatikan tingkat kebutuhannya. Konsumen agar tidak membeli air minum dalam kemasan jika memiliki akses yang mudah terhadap air bersih, misalnya telah memiliki sumber mata air atau sumur yang airnya jernih serta tidak menyisakan air dalam kemasan begitu saja kemudian membuangnya dengan percuma. Sikap-sikap tersebut perlu dijaga sebagai suatu respon etis terhadap persoalan air dalam kemasan yang banyak dirasakan oleh penduduk di sekitar sumber mata air yang diperdagangkan oleh perusahaan air minum, seperti sumber mata air Sigedang di Klaten, Jawa Tengah; dengan begitu jelas menunjukkan kerugian yang dialami oleh masyarakat oleh adanya pengelolaan air oleh swasta, seperti perusahaan air minum Aqua-Danone, terutama ketersediaan (availability) air yang tidak terpenuhi akibat eksploitasi pihak swasta tanpa batas yang jelas. ${ }^{34}$

Islam yang menekankan keadilan dan persamaan hak atas setiap orang dan masyarakat mengajarkan umatnya agar melakukan pertimbangan-pertimbangan moral individu dalam mewujudkan keadilan sosial dan melakukan perlawanan terhadap segala bentuk kecurangan-kecurangan dalam pengambilan sumber daya air. Islam perlu membuat sistem hukum untuk menekankan pentingnya penjagaan sumber daya alam dalam bentuk peningkatan sikap-sikap individu.

Adanya privatisasi air memunculkan ketidakadilan antara masyarakat kaya dan miskin. Masyarakat miskin yang kesulitan air harus membeli air lebih mahal meski konsumsi mereka terhadap air lebih sedikit dibandingkan orang kaya. Kondisi ini terjadi di beberapa negara berkembang, bahwa orang miskin harus membeli air kepada penjaja keliling, sepuluh kali lipat dari harga yang dikeluarkan orang kaya untuk keperluan air. Hal ini karena orang miskin sering dilupakan dan diakhirkan dalam prioritas untuk mendapatkan pelayanan air pipa dari pemerintah. Sebaliknya, mereka yang kaya mendapatkan hak yang istimewa dalam berbagai hal pelayanan pemerintah, seperti pelayanan listrik dan air pipa. ${ }^{35}$ Ketidakadilan ini menjadi tantangan bagi prinsip keadilan dalam Islam. Keadilan dapat dan semestinya

${ }^{34}$ Tim Walhi, (2006) "Nenolak Undang-Undang No. 7 Tahun 2004 (Undang-Undang tentang Sumber Daya Air)," dalam http://www.walhi.or.id/kampanye/air/privatisasi/050427 tolakuusdair_sp/ , dikutip tgl 1 November 2006. 
ditegakkan untuk mencapai pemanfaatan air secara optimal berdasarkan prinsipprinsip ajaran Islam. Hal yang nyata saat ini, bahwa kesadaran akan perlunya menetapkan ajaran agama dalam kehidupan sehari-hari secara lebih dalam, diharapkan dapat menjawab permasalahan yang ada.

\section{E. Kesimpulan}

Kelebihan penduduk dan konsumsi betlebihan menyebabkan munculnya beragam masalah, baik akibat secara langsung maupun tidak langsung terhadap keberlanjutan hidup manusia berikutnya. Dampak terbesar dari kelebihan penduduk dan konsumsi berlebihan adalah krisis lingkungan. Keduanya merupakan penyebab terbesar dari munculnya berbagai masalah lingkungan, di antaranya adalah polusi udara, air, dan tanah. Sehingga solusi terhadap krisis lingkungan perlu juga memperhatikan pengawasan terhadap pertambahan jumlah penduduk dan tingkat konsumsi masyarakat dengan meningkatkan peran agamawan dalam merespon persoalan-persoalan lingkungan dan melakukan kontrol terhadap kebijakan-kebijakan pemerintah.

Adapun mengenai respon Muslim terhadap persoalan air masih betupa tespon umum terhadap persoalan distribusi sumber daya alam dan krisis lingkungan, seperti yang dilakukan oleh Nawal H. Ammar. Sebenarnya diperlukan respon khusus terhadap krisis air katena air merupakan hal yang terpenting dalam kehidupan manusia juga dalam ritual keagamaan. Selain itu, persoalan air juga cukup kompleks, jika tidak dikaji mendalam dan diberi respon yang jelas dari ulama, maka diperkirakan akan sulit untuk mengatasi krisis air. Akibatnya, mungkin krisis air ini akan semakin meningkat dan berlanjut terus sepanjang masa dan menjadi krisis yang telah membunuh ribuan orang di bumi.

Ketidaksetaraan akses air bersih merupakan pola konsumsi manusia yang berlebihan dan bukan hanya dalam hal air, namun juga dalam mengkonsumsi makanan, sandang, maupun papan. Konsumsi dalam hal ini bukan hanya ait sebagai minuman, namun juga dalam bentuk penggunaan air lainnya, seperti memasak, mencuci pakaian, mencuci kendaraan, mandi, menyiram tanaman, bahkan bersuci (wudhu dan mandi wajib). Sehingga respon yang diberikan adalah menjelaskan tentang ayat-ayat al-Qur'an yang melarang manusia untuk berlebih-lebihan dalam hal makan dan minum, serta hadis Nabi yang mengingatkan untuk bersikap hemat dan hati-hati dalam penggunaan air.

Sedangkan kelebihan penduduk sebagai penyebab dari munculnya krisis air dunia pun perlu dibahas. Pelaksanaan program keluarga berencana tidak hanya

${ }^{35}$ Hani Mumtazah (2006), "Water for People, Water for Life, For the Right Price," 02/07/2003, dalam www.islamonline.net/health\&science, diakses tgl. 30 Oktober 2006. 
dilaksanakan dengan tujuan mensejahterakan kehidupan masyarakat, namun sebagai . program dalam mengurangi dampak yang ditimbulkan dari jumlah penduduk yang semakin banyak.

Sebagai respon umum terhadap semua persoalan-persoalan yang terkait dengan pemanfaatan sumber daya alam, konsumsi berlebihan, maupun kelebihan penduduk, adalah perlunya memperhatikan tiga hal, yaitu prinsip keadilan, keseimbangan, dan kehati-hatian. Adil dalam menempatkan keinginan-keinginan, sehingga tidak hanya mengutamakan keinginan dan kepentingan pribadi atas keinginan atau kepentingan orang banyak; seimbang dalam menggunakan sumber daya alam sehingga bersikap lebih hati-hati dalam bersikap, baik terhadap diri sendiri maupun terhadap orang lain.

Kajian mengenai respon Islam atas kualitas air saat ini masih diperlukan. Air sebagai kebutuhan untuk konsumsi minum manusia merupakan air dalam keadaan yang bersih dan sehat, sedangkan dalam pelaksanaan ibadah, terdapat syarat bahwa air suci untuk beribadah adalah air yang tidak betubah warna, bau, dan tasa, sehingga respon terhadap kualitas air ini perlu menjadi kajian lanjutan dalam hal respon etis terhadap krisis air dunia.

Beberapa usaha yang dapat dilakukan adalah penyampaian informasi mengenai kondisi alam dan etika lingkungan dalam media massa dan pendidjkan di sekolahsekolah. Sebagai suatu gambaran adalah dengan menggiatkan para murid dalam kegiatan penjagaan lingkungan dengan mengajak para murid untuk melihat langsung kondisi sekitarnya serta di wilayah-wilayah yang mengalami kerusakan lingkungan. Tidak hanya pendidikan formal namun pendidikan dalam keluarga juga penting dalam pembentukan sikap individu. Harapan kita terhadap perubahan keadaan tidak akan terujud dalam sekejap mata, namun usaha-usaha yang dilakukan secara sistematis dan berkesinambungan oleh berbagai pihak dengan melakukan kerjasama-kerjasama akan membawa perubahan yang cukup berarti di masa yang akan datang. Semestinya krisis lingkungan ini mendapat perhatian khusus dari para tokoh agama, ulama, lembaga pendidikan agama, dan organisasi-organisasi agama sehingga peran agama tethadap pembentukan moral manusia dapat terujud nyata. 


\section{DAFTAR PUSTAKA}

Asmal, Abdul Cader Asmal dan Mohammed (2000), "An Islamic Perspective," dalam Consumption, Population, and-Sustainability: Perspectives from Science and Religion, USA: Island Press.

American Heritage, (1992), The American Heritage Dictionary of the English Language,

$3^{\text {rd }}$ edition, United States of America: Houghton Mifflin Company.

Chapman,Audrey R. (2000), "Introduction", dalam Consumption, Population, and Sustainability: Perspectives from Science and Religion, California: Island Press.

Biocrawlet,"Overpopulation," http://www.biocraweler.com/encyclopedia/Overpopulation, dikutip tgl. 20 Mei 2006.

Lomborg, Bjørn (2001), The Skeptical Envirnmentalis, United Kingdom: Cambridge University Press.

Esack,Farid (2006) “Liberation Theology, Disesase \& Power" pada tanggal 1 Juni 2006, di Program Studi Agama dan Lintas Budaya/CRCS, Sekolah Pascasarjana UGM, Yogyakarta.

Gatdner, Gary (2002), Invoking the Spirit: Religion and Spirituality in the Quest for a Sustainable World, USA: Worldwatch Institute.

Mumtazah, Hani (2006) "Water for People, Water for Life, For the Right Price," 02/ 07/2003, www.islamonline.net/health\&science, dikutip tgl. 30 Oktober 2006. Ozdemir, Ibrahim (2003), "Environmental Ethics from a Qur'anic Perspective," dalam Islam and Ecology: $A$ Bestowed Trust, R. Foltz, F. Denny, dan A. Baharuddin ed., Cambridge: Harvard University Press.

Kuntowijoyo (1990), "Dari Rasionalitas Menuju Transendensi," dalam Inovasi No. 7 Th. IV.

White Jr., Lynn (2003), "The Historical Roots of Our Ecologic Crisis," dalam Worldviews, Religion, and the Environment: A Global Antbology, Richard C. Foltz ed., USA: Thomson Wadsworth.

Llewellyn, Othman Abd-Ar-Rahman (2003), "The Basis for a Discipline of Islamic Environmental Law," dalam Islam and Ecology: $A$ Bestowed Trust, R. Foltz, F. Denny, dan A. Baharuddin ed., Cambridge: Harvard University Press.

Foltz, Richard C. (2005), "Water in Islam," dalam Encyclopedia of Religion and Nature Volume II, Bron R. Taylor ed., London \& New York: Thoemmes Continuum. Salam Tribun (2006), "Menghadapi Bencana Alam", dalam Tribun Timur, Rabu, 27 Desember 2006.

Sutikno dan Maryunani (2006), Ekonomi Sumber Daya Alam, Malang: Badan Penerbit Fakultas Ekonomi UNIBRAW.

The World Bank (2006), "Population Growth Rate," dalam www.worldbank/org/ depweb/english/modules/social/pgr/chart2, diakses tgl. 10 Agustus 2006. 
The World Bank, "Population Growth Rate," www.worldbank.org/depweb/english/ modules/social/pgr/chart1

Narayanan, Vasudha (2001), "Water, Wood, and Wisdom: Ecological Perspectives from the Hindu Traditions," dalam Daedalus, Journal of the American Academy of Arts and Sciences.

Walhi, "Menolak Undang-Undang No. 7 Tahun 2004 (Undang-Undang tentang Sumber Daya Air)," http://www.walhi.or.id/kampanye/air/privatisasi/ 050427_tolakuusdair_sp/, dikutip tgl 1 November 2006. 